\title{
Nitrogen Use Efficiency and Performance of Wheat Crop Through Application of Urea Stable and Conventional Urea in Vertisols of Ambo District
}

\author{
Tolcha Tufa", Tolera Abera, Tesfaye Midega, Adane Adugna, Hirpa Legesse, Bezuayehu Tola \\ Natural Resources Management Research Process, Ambo Agricultural Research Center, Ethiopian Institute of Agricultural Research, Addis \\ Ababa, Ethiopia
}

Email address:

tolch140@gmail.com (T. Tufa), thawwii2014@gmail.com (T. Tufa)

${ }^{*}$ Corresponding author

\section{To cite this article:}

Tolcha Tufa, Tolera Abera, Tesfaye Midega, Adane Adugna, Hirpa Legesse, Bezuayehu Tola. Nitrogen Use Efficiency and Performance of Wheat Crop Through Application of Urea Stable and Conventional Urea in Vertisols of Ambo District. Plant. Vol. 8, No. 4, 2020 , pp. $72-79$. doi: 10.11648/j.plant.20200803.14

Received: September 25, 2020; Accepted: October 13, 2020; Published: November 23, 2020

\begin{abstract}
Nitrogen is the most yield liming nutrient that can be highly soluble and lost through leaching, volatilization and denitrification. In this view an experiment was conducted to determine the effects of urea stable and convectional urea on nitrogen use efficiency and crop performance of wheat in Vertisols of Ambo District, west Shewa Zone. The experiment was laid out in randomized complete block design with three replications. The treatments were different rate of urea stable and convectional urea applied at planting and in split: (Control, $23 \mathrm{~kg} \mathrm{~N}^{-1}$ from urea stable applied once at planting, $23 \mathrm{~kg} \mathrm{~N}^{-1}$ from urea stable in

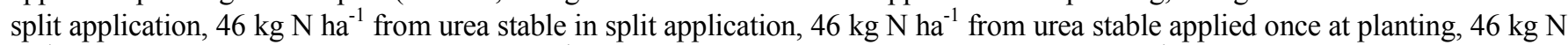
$\mathrm{ha}^{-1}$ from urea in split application, $69 \mathrm{~kg} \mathrm{~N} \mathrm{ha}^{-1}$ from urea stable in split application, $69 \mathrm{~kg} \mathrm{~N}^{-1}{ }^{-1}$ from urea in split application, 69 $\mathrm{kg} \mathrm{N} \mathrm{ha}^{-1}$ from urea stable applied once at planting). Agronomic use efficiency was significantly varied among applied urea stable and convectional urea during first year. Significantly higher (32.77 and $40.8 \mathrm{~kg}$ grain/ $\mathrm{kg} \mathrm{N}$ applied) agronomic efficiency of wheat from farm one (1) and two (2) were recorded by application of $23 \mathrm{~kg} \mathrm{~N} \mathrm{ha}^{-1}$ from urea stable in split form. Mean grain yield, dry biomass, harvest index, plant height and spike length of wheat were significantly affected with application of urea stable and convectional urea. The highest mean spike length $(6.6 \mathrm{~cm})$, plant height $(80 \mathrm{~cm})$, harvest index $(45 \%)$ and thousand seed weight (45g) were recorded from split application of $69 \mathrm{~kg} \mathrm{~N} \mathrm{ha}^{-1}$ in the form of urea stable fertilizer. Wheat grain yield of $3623 \mathrm{~kg} \mathrm{ha}^{-1}$ and dry biomass $8921 \mathrm{~kg} \mathrm{ha}^{-1}$ were recorded from split application of $69 \mathrm{~kg} \mathrm{~N} \mathrm{ha}^{-1}$ from conventional urea fertilizer. Statistically significant difference of yield and yield components of wheat were not observed by applying similar rate of urea stable and convectional urea. Therefore, urea stable and convectional urea could be used as alternatively for wheat production in study area.
\end{abstract}

Keywords: Urea Stable, Wheat, Nitrogen, Nutrient Use Efficiency

\section{Introduction}

Nitrogen is the most limiting nutrient for agricultural production worldwide and application of nitrogen fertilizer is generally required for optimum yield of most crops $[1,2]$. It is required by plants comparatively in larger amounts than other essential plant nutrients [3]. Inadequate or absence of nitrogen fertilizer application on soil with insufficient endogenous nitrogen can cause much yield reduction than other plant nutrients [4]. Excess application and misuse of nitrogen fertilizer is result in environment pollution and low resource use efficiency or low return investment of the farmers [5]. Nitrogen use efficiency can be low due to different factors such as nitrogen sources, climate, soil condition, dose of $\mathrm{N}$ applied and time of application [6]. The crops use only $50-60 \%$ of applied $\mathrm{N}$ and less than half amount of $\mathrm{N}$ applied in most case [7, 8]. Therefore, applying optimum rate at the right time from good nitrogen source can increase crop yield, reduce nitrogen lose and improve nitrogen use efficiency [9]. A number of studies were also done to find the optimum rate and time of nitrogen application to improve wheat yield, nutrient use efficiencies 
and to reduce environmental pollution [10]. Convectional urea is exposed to urease enzyme activities that found in plants, bacteria, fungi and algae. Urease enzyme is result in low nitrogen use efficiency [1]. Therefore, efforts have made by fertilizer producers to produce urease activity inhibitors that can increase efficiency of applied urea by inhibiting urease enzyme activity in the soil [11].

Ethiopia is the largest wheat producers in sub-Saharan Africa. It is cultivated approximately on 1.7 million hectares of land and ranks fourth next to teff, maize and sorghum both in production and area coverage [12]. However, the yield of this crop is low in Ethiopia due to different factors and the country enforced to import wheat to meet domestic needs [13]. Low soil fertility and insufficient application of fertilizer is mainly responsible for low wheat production in Ethiopia $[14,15]$. Wheat grain yield and seed quality can be highly influenced by $\mathrm{N}$ fertilization and absence of nitrogen application [16]. Thus, the application of the appropriate rate of $\mathrm{N}$ fertilizer at the right time can significantly increase wheat grain yield and improve uptake efficiency as well as protein content of the crop $[9,16]$. However, information on effect of different source of nitrogen fertilizer on wheat production and nitrogen use efficiency in Vertisols of west Showa zone is limited. Therefore, the objective was to determine effect urea stable and conventional urea fertilizer rate on nitrogen use efficiency and performance of wheat crop in Vertisols of Ambo district, west Showa zone.

\section{Materials and Methods}

\subsection{Description of Study Area}

The study was conducted for two consecutive years during 2018 and 2019 main cropping seasons on Vertisols of Ambo district. During the two-cropping season the experiment was executed on four farmer's field. Geographically, the district is located between $8^{\circ} 52^{\prime} 30^{\prime \prime}-9^{\circ} 32^{\prime} 30^{\prime \prime} \mathrm{N}$ latitude $37^{\circ} 31^{\prime} 50^{\prime \prime}$ $38^{\circ} 1$ ' $40^{\prime \prime} \mathrm{N} E$ longitudes. The area receives mean annual rain fall of $1036.24 \mathrm{~mm}$ with unimodal distribution. It has a cool humid climate with the mean minimum, mean maximum, and average air temperatures of $10.26,26.21^{\circ} \mathrm{C}$ and 18.24, respectively. The dominant soil type of the area is Vertisols which are known for their high-water logging and drainage problems [17].

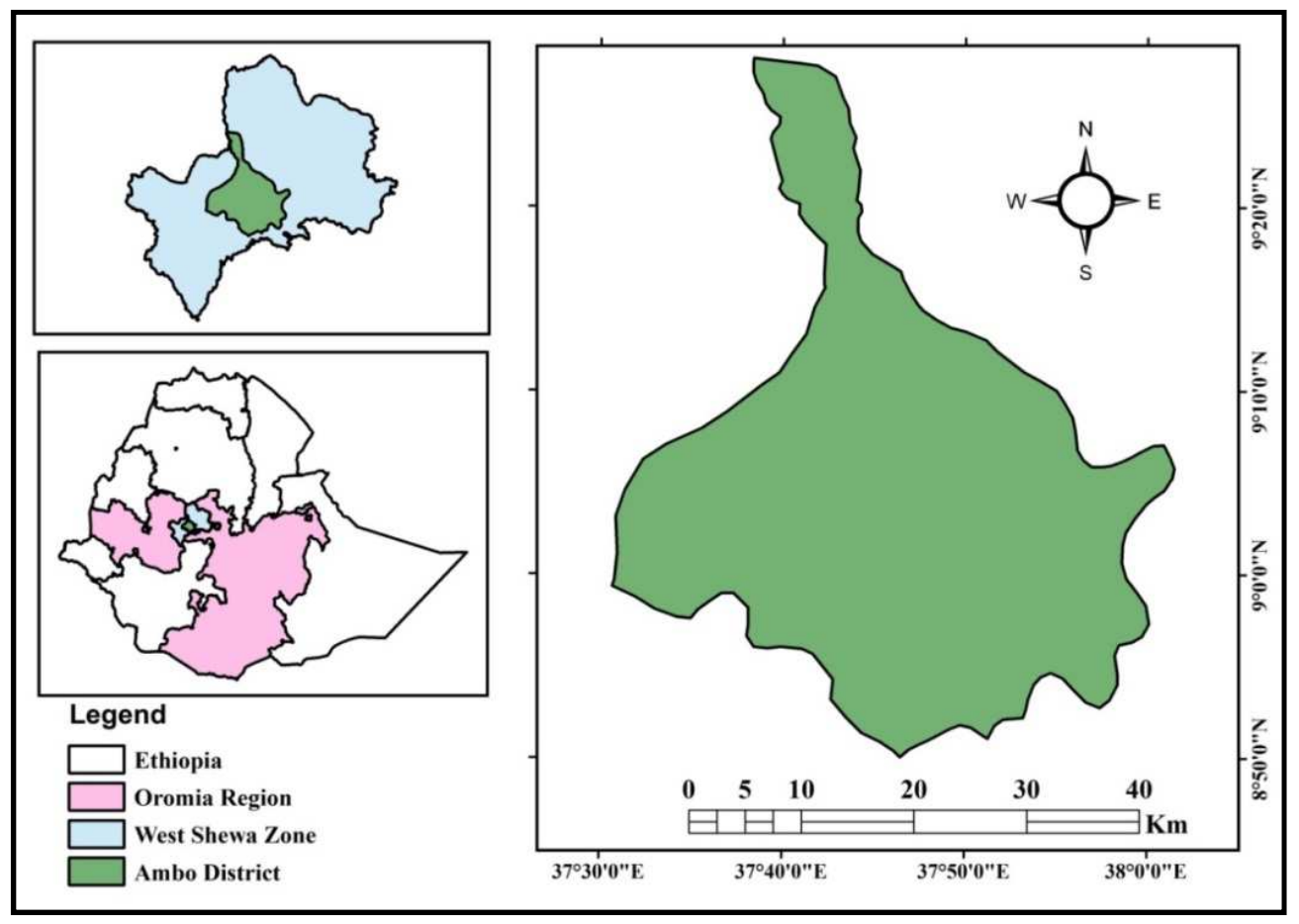

Figure 1. Map of experimental Site (Ambo District).

\subsection{Experimental Design and Treatments}

The experiment was laid out in randomized complete block design with three replications. The plot size of $3 \mathrm{~m} \times 3$ $\mathrm{m}$ was used during both years. The treatments consisted different rate of urea stable and normal urea with different application time. Wane improved wheat variety was planted on first week of July using $20 \mathrm{~cm}$ recommended row spacing and $150 \mathrm{~kg} / \mathrm{ha}$ seeding rate. Nitrogen from urea stable and normal urea was applied as per as described in treatment set up. However, recommended rate of phosphorus $\left(26 \mathrm{~kg} \mathrm{P} \mathrm{ha}^{-1}\right)$ from TSP was uniformly applied during planting. Recommended agronomic practices like ploughing and hand weeding were uniformly adapted to all plots.

\subsection{Soil and Plant Tissue Sampling and Analysis}

Prior to planting 10 soil samples were collected to the depth of $0-20 \mathrm{~cm}$ across the experimental field. Immediately after sampling the total of 10 samples were thoroughly mixed in the field, about $1 \mathrm{~kg}$ composite and homogenized sample was taken and put into the labeled plastic bag. After harvesting, soil 
samples were collected from all plots in the experimental field. The samples were taken from central rows of the plots to reduce boarder effect. Then the sample were taken to Ambo Agricultural research Center for sample preparation. Then the soil samples were spread on the sheet and dried with aid of air in the room. The air-dried soil samples were milled using mortar and Pestle, then sieved through a $2 \mathrm{~mm}$ diameter sieve for analysis of nitrogen. The tissue of wheat was collected at $50 \%$ booming of wheat. Then the wheat straw was chopped and air dried with grain in the room. The grain of wheat was collected after harvesting of the crop. Finally, both soil and plant sample were taken to Kulumsa and Holetta Agricultural Research Center soil and plant laboratory for nitrogen and other soil parameters analysis.

The soil and plant samples were analyzed at Kulumsa and Holetta Agricultural Research Center Soil and Plant Laboratory. Particle size distribution (texture), soil $\mathrm{pH}$, organic carbon (OC), total $\mathrm{N}$, available $\mathrm{P}$, cation exchange capacity (CEC) was analyzed using standard procedures. Determination of soil particle size distribution was carried out using the hydrometer method [18]. The soil $\mathrm{pH}$ was measured with digital $\mathrm{pH}$ meter potentiometrically in the supernatant suspension of 1:2.5 soils to water ratio. Organic carbon was determined following wet digestion methods as described by Walkley and Black [19], whereas kjeldahl procedure was used for the determination of total nitrogen as described by [20]. Cation exchange capacity of the soil (CEC) was determined by saturating soil with neutral $1 \mathrm{M}$ $\mathrm{NH}_{4} \mathrm{OAc}$ (ammonium acetate) and the adsorbed $\mathrm{NH}^{+}$ions were displaced by using $1 \mathrm{M} \mathrm{KCl}$ and then determined by the Kjeldahl distillation method for estimation of CEC of the soil $[21,22]$. The available $\mathrm{P}$ was measured by Bray II method [23].

The wheat tissues and grain were subjected to wet digestion using concentrated sulphuric acid and hydrogen per-oxide with selenium as catalyst [24] and the $\mathrm{N}$ content of the plant tissue was determined by Kjeldahl methods. Total $\mathrm{N}$ uptake was calculated by multiplying $\mathrm{N}$ concentration by dry biomass weight $\left(\mathrm{kg} \mathrm{ha}^{-1}\right)$ of wheat. Agronomic efficiency was calculated by multiplying the grain yield and applied $\mathrm{N}$ [25].

$$
\mathrm{AE}(\mathrm{kg} \text { grain } / \mathrm{kgN})=\frac{\mathrm{Yn}-\mathrm{Yo}}{\mathrm{Fn}}
$$

Whereas $\mathrm{AE}=$ Agronomic efficiency $\mathrm{Yn}$ and Yo are the grain yield with or without $\mathrm{N}$ applied respectively and $\mathrm{Fn}$ is the amount of nitrogen fertilizer applied

Apparent fertilizer $\mathrm{N}$ use (recovery) efficiency (ANRE) was obtained by dividing the amount of fertilizer $\mathrm{N}$ taken up by the plant to the $\mathrm{kg}$ of $\mathrm{N}$ applied as fertilizer as it was described by (26)

$$
\operatorname{ARE}(\operatorname{KgN} / \mathrm{kgN})=\frac{\text { Un-Uo }}{\mathrm{Fn}}
$$

Where $\mathrm{ARE}=$ Apparent recovery efficiency, Un and Uo are nutrient uptake in fertilized and control plot respectively; Fn is the amount of $\mathrm{N}$ fertilizer applied.

Plant nitrogen use efficiency/ physiological efficiency was calculated by dividing the total dry matter produced to a unit of $\mathrm{N}$ absorbed as indicated below:

$$
\mathrm{PE} \mathrm{kg} \mathrm{grain} / \mathrm{kgN}=\frac{\mathrm{Yn}-\mathrm{Yo}}{\mathrm{Un}-\mathrm{Uo}}
$$

Where $\mathrm{PE}=$ physiological efficiency, Un and Uo are nutrient uptake in fertilized and control plot respectively; Yn and Yo are the grain yield in fertilized and control plot respectively

\subsection{Agronomic Data Collection}

Data on growth parameters yield and yield components of wheat were collected from the central rows of each plot. Agronomic data such as plant height and spike length were measured before harvesting or at grain filling stage. The plant height measured from the base of the plant at ground level to the base of spike for 10 randomly selected plants. At physiological maturity, wheat samples were harvested from central rows and threshed to measure weight of both grain and dry biomass using digital balance. Dry biomass, grain yield and 1000 seed weight were recorded after harvesting and threshing. Harvesting index was calculated from the ratio of grain yield and above ground biomass times 100 .

\subsection{Statistical Analysis}

The collected data were analyzed using SAS computer software version 9.13 [27]. Whenever treatment effects were significant, the means was separated using the least significant difference procedures test at 5\% level of significance [28].

\section{Results and Discussion}

\subsection{Some Soil Chemical and Physical Properties of the Study Area}

The physicochemical properties of different farmers' field during 2018 cropping season were indicated in Table 1. The soil distribution of both farm fields was clay in textural classes. The soil $\mathrm{pH}$ of experimental field at Bayo Kurbi and Amaro kebele were 6.45 and 6.10 , respectively and slightly acidic in soil reaction [29]. The organic carbon contents of soil were 1.85 and $2.02 \%$ found in high range of organic carbon rate [29]. The nitrogen content of study area soil was 0.13 (low) and $0.09 \%$ (medium) at Bayo Kurbi and Amaro kebele farmer's field respectively [29]. Available phosphorus of soil was very low (8.9 ppm) and low (12.42ppm) at Amaro

\begin{tabular}{|c|c|c|c|c|c|c|c|c|c|}
\hline \multirow[t]{2}{*}{ Kebele } & \multicolumn{3}{|c|}{ Soil texture } & \multirow{2}{*}{$\mathbf{p H}$} & \multirow{2}{*}{$\begin{array}{l}\text { Available } \\
\text { P }\end{array}$} & \multirow{2}{*}{$\begin{array}{l}\text { Total N } \\
(\%)\end{array}$} & \multirow{2}{*}{ CEC (cmol+/kg) } & OC & \multirow[t]{2}{*}{ OM } \\
\hline & Clay & Silt & (pmm) sand & & & & & $\%$ & \\
\hline Bayo kurbi & 67.46 & 20.36 & 12.18 & 6.45 & 12.42 & 0.09 & 44.26 & 1.08 & 1.86 \\
\hline Amaro & 66.43 & 21.84 & 10.73 & 6.10 & 8.9 & 0.13 & 46.34 & 2.02 & 3.47 \\
\hline
\end{tabular}
and Bayo Kurbi respectively [30].

Table 1. Some physical and chemical properties of soil of experimental site before planting in 2018 cropping season. 


\subsection{Effect of Urea Stable and Conventional Urea on Growth, Yield and Yield Components of Wheat}

The combined analysis of variance showed non-significant $(p>0.05)$ effect of cropping year variation on mean plant height, dry biomass, spike length, grain yield and harvest index of wheat. This indicates similar climate condition such as rain fall pattern and distribution during two cropping seasons in the area. Interaction effect of treatment by year (trt *year) was non-significant $(\mathrm{p}<0.05)$ for all parameters. Therefore, only treatment effect (nitrogen rate) on growth parameters, yield and yield components of wheat crop was discussed in the manuscript.

\subsubsection{Plant Height and Spike Length}

Effect of nitrogen rate was significant on mean plant height irrespective of nitrogen source and application time of slow releasing urea stable and conventional urea (Table 2). The mean plant height of wheat was showed increasing trend with increasing rate of nitrogen applied. This indicated the positive effect of $\mathrm{N}$ on vigorous vegetative growth and internodal extension due to more availability of $\mathrm{N}$ throughout the growing period. Wheat plant height was ranged from 60 to $80 \mathrm{~cm}$ whereas the lower and higher value of the plant height wheat was recorded from control and application of $69 \mathrm{~kg} \mathrm{~N}$ $\mathrm{ha}^{-1}$ from urea stable in split (Table 2). The plant height recorded by application of $69 \mathrm{~kg} \mathrm{~N} \mathrm{ha}^{-1}$ from urea stable in split was statistically at par with plant height measured from plot treated with the same amount of nitrogen from urea stable applied only at planting and normal urea applied in split. This indicates similar effects of nitrogen from urea stable and normal urea on plant height of wheat. [31] also recorded statistically similar plant height from plot received $\mathrm{N}$ from conventional urea and urea with inhibitors. Similarly, [32] also reported significant effects of application time and rate of urea fertilizer in Haramaya and Meta sites. The authors recorded taller plant height of $(115 \mathrm{~cm})$ wheat from $138 \mathrm{~kg} \mathrm{~N} \mathrm{ha}^{-1}$ applied in two splits of $1 / 2$ dose at midtillering and $1 / 2$ at anthesis of wheat.

Table 2. Effect of urea stable on mean plant height and spike length of wheat in 2018 and 2019 cropping season and combined over years.

\begin{tabular}{|c|c|c|c|c|c|c|}
\hline \multirow{2}{*}{ Treatment (kg N ha $\left.{ }^{-1}\right)$} & \multicolumn{3}{|c|}{ Plant height (cm) } & \multicolumn{3}{|c|}{ Spike length (cm) } \\
\hline & 2018 & 2018 & Mean & 2018 & 2019 & Mean \\
\hline 0 & $65^{\mathrm{e}}$ & $61.8^{\mathrm{c}}$ & $64^{\mathrm{f}}$ & $4.9^{\mathrm{d}}$ & $4.8^{\mathrm{d}}$ & $4.8^{\mathrm{d}}$ \\
\hline $46 \mathrm{~N}$ from NU. in split & $75^{\mathrm{abc}}$ & $75.5^{\mathrm{ab}}$ & $75^{\mathrm{cd}}$ & $5.9^{\mathrm{bc}}$ & $5.9^{\mathrm{ab}}$ & $5.9^{\mathrm{c}}$ \\
\hline $46 \mathrm{~N}$ from US. at planting & $69^{\mathrm{de}}$ & $70.6^{\mathrm{b}}$ & $70^{\mathrm{e}}$ & $5.8^{\mathrm{c}}$ & $5.2^{\mathrm{cd}}$ & $5.6^{\mathrm{c}}$ \\
\hline $46 \mathrm{~N}$ from US. in split & $73^{\text {cd }}$ & $71.4^{\mathrm{b}}$ & $72^{\mathrm{de}}$ & $5.8^{\mathrm{c}}$ & $5.4^{\mathrm{bc}}$ & $5.7^{\mathrm{c}}$ \\
\hline $23 \mathrm{~N}$ from US. at planting & $75^{\mathrm{abc}}$ & $76.8^{\mathrm{ab}}$ & $75^{\text {bcd }}$ & $6.2^{\mathrm{abc}}$ & $5.5^{\mathrm{bc}}$ & $5.9^{\mathrm{bc}}$ \\
\hline $23 \mathrm{~N}$ from US. in split & $74^{\text {bcd }}$ & $78.2^{\mathrm{ab}}$ & $75^{\mathrm{cd}}$ & $6.1^{\mathrm{abc}}$ & $5.8^{\mathrm{abc}}$ & $6^{\mathrm{abc}}$ \\
\hline $69 \mathrm{~N}$ from US in split & $79^{\mathrm{a}}$ & $81.5^{\mathrm{a}}$ & $80^{\mathrm{a}}$ & $6.9^{\mathrm{a}}$ & $6^{\mathrm{ab}}$ & $6.6^{\mathrm{a}}$ \\
\hline $69 \mathrm{~N}$ from NU in split & $78^{\mathrm{ab}}$ & $82.3^{\mathrm{a}}$ & $79^{\mathrm{ab}}$ & $6.3^{\mathrm{abc}}$ & $5.9^{\mathrm{ab}}$ & $6.1^{\mathrm{abc}}$ \\
\hline $69 \mathrm{~N}$ from US at planting & $76^{\mathrm{abc}}$ & $79.8^{\mathrm{a}}$ & $77^{\mathrm{abc}}$ & $6.6^{\mathrm{ab}}$ & $6.2^{\mathrm{a}}$ & $6.5^{\mathrm{ab}}$ \\
\hline LSD (5\%) & 4.5 & 7.8 & 3.86 & 0.78 & 0.6 & 0.57 \\
\hline CV (\%) & 5.2 & 6 & 5.5 & 11 & 6.3 & 10.2 \\
\hline
\end{tabular}

$\mathrm{US}=$ urea stable, $\mathrm{NU}=$ normal urea, $\mathrm{NS}=$ nonsignificant difference at $5 \%$ probability level; numbers followed by same letter in the same column are not significantly different at $5 \%$ probability level.

Mean spike length of wheat was also significantly $(\mathrm{P}<0.05)$ affected by different rate of nitrogen fertilizers (Table 2). Mean spike length measured from similar urea stable fertilizer rate applied once at planting and applied in split was statistically similar. There was also no significant difference among mean spike length recorded from application of similar rate of urea stable and conventional urea. Higher spike length was measured from plots received high rates of nitrogen fertilizer. This could be due to the availability of nitrogen in significant quantity to keep the plant healthy which contributed for normal growth and spike length of wheat. Similarly, statistically significant effects of timing of the $\mathrm{N}$ fertilizer application and $\mathrm{N}$ fertilizer rate on wheat spike length were reported by [32] in eastern Ethiopia.

\subsubsection{Dry Biomass and Grain Yield of Wheat}

The mean grain yield of wheat was significantly $(\mathrm{P}<0.05)$ affected by nitrogen rate in irrespective to nitrogen source used in the experiment (Table 3). Higher mean grain yield of (3623 $\mathrm{kg} \mathrm{ha}^{-1}$ ) was obtained from application of $69 \mathrm{~kg} \mathrm{~N} \mathrm{ha}^{-1}$ from urea stable fertilizer applied in split. Statistically similar grain yield of $3622 \mathrm{~kg} \mathrm{ha}^{-1}$ was obtained from application of $69 \mathrm{~kg} \mathrm{~N}$ $\mathrm{ha}^{-1}$ applied in split in the form of conventional urea. However, [33] reported significant effect of nitrogen rate and sources on grain yield of wheat in Tigray region. Statistically significant effect of application time of urea stable at each similar rate was not observed and this this can be due slow releasing of nitrogen from urea stable fertilizer. Similarly, [32] reported highly significant $(\mathrm{P}<0.01)$ influence of $\mathrm{N}$ fertilizer rate and time of application on grain yield of wheat in Meta district. Also, [34] also reported significant effect nitrogen fertilizer rate on mean grain yield of wheat crop. Application of nitrogen up to $69 \mathrm{~kg} \mathrm{~N}$ ha $^{-1}$ was significantly $(\mathrm{P}<0.01)$ improved wheat grain yield while further increasing of nitrogen above $69 \mathrm{~kg} \mathrm{~N}$ $\mathrm{ha}^{-1}$ was significantly reduced wheat grain yield in Enderta district of Tigray region [35]. 
Table 3. Effect of urea stable and urea on mean grain yield and dry biomass of wheat in 2018, 2019 cropping season and combined over years.

\begin{tabular}{|c|c|c|c|c|c|c|}
\hline \multirow{2}{*}{$\begin{array}{l}\text { Treatments } \\
\left(\mathrm{Kg} \mathrm{N} \mathrm{ha}^{-1}\right)\end{array}$} & \multicolumn{3}{|c|}{ Grain yield $\left(\mathrm{kg} \mathrm{ha}^{-1}\right)$} & \multicolumn{3}{|c|}{ Dry biomass $\left(\mathrm{kg} \mathrm{ha}^{-1}\right)$} \\
\hline & 2018 & 2019 & Mean & 2018 & 2019 & Mean \\
\hline 0 & $1790^{\mathrm{e}}$ & $1682^{\mathrm{e}}$ & $1754^{\mathrm{e}}$ & $4444^{\mathrm{e}}$ & $4803^{\mathrm{d}}$ & $4564^{\mathrm{f}}$ \\
\hline $46 \mathrm{~N}$ from NU. in split & $3000^{\mathrm{bc}}$ & $3381^{\mathrm{abc}}$ & $3127^{\mathrm{bc}}$ & $7148^{\mathrm{bc}}$ & $8651^{\mathrm{ab}}$ & $7649^{\text {bc }}$ \\
\hline $46 \mathrm{~N}$ from US. at planting & $2753^{\mathrm{cd}}$ & $3000^{\text {bc }}$ & $2835^{\mathrm{bc}}$ & $6488^{\text {cd }}$ & $7556^{\mathrm{bc}}$ & $6844^{\mathrm{bc}}$ \\
\hline $46 \mathrm{~N}$ from US. in split & $2802^{\text {cd }}$ & $3317^{\mathrm{c}}$ & $2974^{\mathrm{bc}}$ & $6840^{\mathrm{bc}}$ & $8603^{\mathrm{ab}}$ & $7427^{\mathrm{bc}}$ \\
\hline $23 \mathrm{~N}$ from US. at planting & $2389^{d}$ & $2143^{\text {ed }}$ & $2307^{\mathrm{d}}$ & $5506^{\mathrm{de}}$ & $5286^{\mathrm{d}}$ & $5433^{\mathrm{ef}}$ \\
\hline $23 \mathrm{~N}$ from US. in split & $2636^{\mathrm{cd}}$ & $2698^{\mathrm{dc}}$ & $2657^{\text {cd }}$ & $6136^{\mathrm{cd}}$ & $6524^{\text {cd }}$ & $6265^{\mathrm{de}}$ \\
\hline $69 \mathrm{~N}$ from US in split & $3679^{\mathrm{a}}$ & $3508^{\mathrm{ab}}$ & $3622^{\mathrm{a}}$ & $7908^{\mathrm{ab}}$ & $8841^{\mathrm{ab}}$ & $8219^{\mathrm{ab}}$ \\
\hline $69 \mathrm{~N}$ from NU in split & $3395^{\mathrm{ab}}$ & $4079^{\mathrm{a}}$ & $3623^{\mathrm{a}}$ & $8469^{\mathrm{a}}$ & $9825^{\mathrm{a}}$ & $8921^{\mathrm{a}}$ \\
\hline $69 \mathrm{~N}$ from US at planting & $3086^{\mathrm{bc}}$ & $3270^{\text {bc }}$ & $3147^{\mathrm{ab}}$ & $7006^{\text {bc }}$ & $8159^{\mathrm{abc}}$ & $7390^{\mathrm{bc}}$ \\
\hline LSD (5\%) & 547 & 1942 & 482 & 1188 & 744.9 & 977 \\
\hline CV (\%) & 16.4 & 14.7 & 17.7 & 15.2 & 14.3 & 14.9 \\
\hline
\end{tabular}

Means followed by different letter (s) in a column and rows are significant at $5 \%$ level of probability.

The combined mean dry biomass was significantly $(\mathrm{P}<0.05)$ affected by nitrogen rate applied from urea stable and normal urea (Table 3) and mean dry biomass of wheat was increased with increasing rate of nitrogen fertilizer. Split application of urea stable $\left(69 \mathrm{~kg} \mathrm{~N} \mathrm{ha}^{-1}\right)$ provided $8921 \mathrm{~kg} \mathrm{ha}^{-}$ ${ }^{1}$ mean dry biomass. This was statistically at par with mean dry biomass of 8190 and $8219 \mathrm{~kg} \mathrm{ha}^{-1}$ recorded from split application of $69 \mathrm{~kg} \mathrm{~N} \mathrm{ha}^{-1}$ from normal urea and $69 \mathrm{~kg} \mathrm{~N} \mathrm{ha}$ ${ }^{1}$ from urea stable applied at planting. Likewise, [34] reported significant effect of nitrogen fertilizer on mean grain yield of wheat varieties in northern Ethiopia. Application of nitrogen rate up to $69 \mathrm{~kg} \mathrm{~N} \mathrm{ha}^{-1}$ was significantly improved the dry biomass of bread wheat and decreased with further increase of applied $\mathrm{N}$ fertilizer [35]. Application of similar rates of nitrogen from urea stable and urea was provided statistically similar dry biomass yields. Similarly, [32] reported nonsignificant effect of normal urea and urea stable on straw yield when applied at similar rate. In contrary, [31] reported significant biomass yield increment by application of urea + inhibitor over application of urea without inhibitor.

\subsubsection{Harvest Index and Thousand Seed Weight}

The mean harvest index and thousand seed weight of wheat due to application of urea stable and conventional urea are indicated in Table 4. Both harvest index and thousand seed weight of wheat crop were significantly $(\mathrm{P}<0.05)$ affected by application of different nitrogen rate from urea stable and conventional urea on Vertisols of Ambo district (Table 4). Mean harvest index and thousand seed weight were showed increasing trend with increasing rate of nitrogen from 23 to $\mathrm{kg}$ $\mathrm{N} \mathrm{ha}^{-1} 69 \mathrm{~kg} \mathrm{~N}^{-1}{ }^{-1}$ when applied both in form of urea stable and conventional urea. However, the effects of application time of urea stable and nitrogen source were insignificant on both parameters. Similarly, [31] also reported statistically similar influence of normal urea and urea with NBPT on 1000 grain weights and harvest indexes of wheat.

The combined mean harvest index of wheat was ranged 38.3 to $44.70 \%$. These figures were recorded from plot treated with nothing $\left(0 \mathrm{~kg} \mathrm{~N} \mathrm{ha}^{-1}\right)$ and $69 \mathrm{~kg} \mathrm{~N}^{-1}$ from urea stable in split application. Similarly, [36] reported statistically higher harvest index $(38 \%)$ of bread wheat with application of higher nitrogen fertilizer $150 \mathrm{~kg} \mathrm{ha}^{-1}$ while the lowest harvest index (34\%) was recorded from control $\left(0 \mathrm{~kg} \mathrm{ha}^{-1}\right)$. The combined mean thousand seed weight of wheat was ranged 37.2 to $45.2 \mathrm{~g}$ obtained with control and application of $69 \mathrm{~kg} \mathrm{~N} \mathrm{ha}^{-1}$ from conventional urea in split application. [36] recorded higher thousand grains weight (44 and $44 \mathrm{~g}$ ) of by applying higher levels of nitrogen fertilizer (150 and $\left.125 \mathrm{~kg} \mathrm{ha}^{-1}\right)$, whereas the lower thousand grains weight $(40 \mathrm{~g})$ was recorded from the control treatment. Therefore, applications of urea fertilizer from urea stable and conventional urea were significantly increased mean harvest index and thousand weight of wheat as compared to the control treatment.

Table 4. Effect of urea stable and conventional urea on mean harvest index and thousand seed weight of wheat in 2018,2019 cropping season and combined over years in Vertisols of Ambo.

\begin{tabular}{|c|c|c|c|c|c|c|}
\hline \multirow{2}{*}{ Treatment (kg N ha $\left.{ }^{-1}\right)$} & \multicolumn{3}{|c|}{ Harvest Index (\%) } & \multicolumn{3}{|c|}{ Thousand seed weight (g) } \\
\hline & 2018 & 2018 & Mean & 2018 & 2019 & Mean \\
\hline 0 & 40.0 & 35 & 38.3 & 37.8 & 38.2 & 37.2 \\
\hline $46 \mathrm{~N}$ from $\mathrm{NU}$. in split & 41.0 & 38.3 & 40.1 & 45.7 & 40.1 & 43.9 \\
\hline $46 \mathrm{~N}$ from US. at planting & 43.8 & 41 & 42.9 & 41.9 & 38.9 & 40.9 \\
\hline $46 \mathrm{~N}$ from US. in split & 43.0 & 41.7 & 42.6 & 41.1 & 39 & 40.4 \\
\hline $23 \mathrm{~N}$ from US. at planting & 42.7 & 39 & 41.4 & 45.7 & 40.6 & 44 \\
\hline $23 \mathrm{~N}$ from US. in split & 42.8 & 39.7 & 41.8 & 45.9 & 39.6 & 43.8 \\
\hline $69 \mathrm{~N}$ from US in split & 47.0 & 40 & 44.7 & 46.9 & 41 & 44.9 \\
\hline $69 \mathrm{~N}$ from NU in split & 41.2 & 41.3 & 41.2 & 46.5 & 42.4 & 45.2 \\
\hline $69 \mathrm{~N}$ from US at planting & 44.5 & 40 & 43 & 46.2 & 39.9 & 44.1 \\
\hline $\operatorname{LSD}(5 \%)$ & NS & 4.02 & 6.3 & 2.02 & 2.3 & 1.68 \\
\hline CV (\%) & 18.2 & 5.9 & 16 & 3.9 & 3.3 & 4.2 \\
\hline
\end{tabular}

$\mathrm{US}=$ urea stable, $\mathrm{NU}=$ normal urea, NS $=$ non-significant difference at $5 \%$ probability level; numbers followed by same letter in the same column are not significantly different at $5 \%$ probability level. 


\subsection{Effects of Urea Stable on Nutrient Use Efficiency of Wheat}

\subsubsection{Agronomic Nitrogen Efficiency}

Agronomic nitrogen efficiency of wheat crop was significantly varied among different rates of urea stable and conventional urea (Table 5). This might be due to increasing of grain yield and biomass with increasing of applied nitrogen rate. The highest $\left(32.77 \mathrm{~kg}_{\text {grain }} \mathrm{kg} \mathrm{N}^{-1}\right)$ and lowest $\left(18.53 \mathrm{~kg}\right.$ grain $\left.\mathrm{kg} \mathrm{N}^{-1}\right)$ agronomic nitrogen efficiency was recorded from $23 \mathrm{~kg} \mathrm{~N} h a^{-1}$ applied as urea stable in split and $46 \mathrm{~kg} \mathrm{~N} \mathrm{ha}^{-1}$ from urea stable applied at planting in farm one. However, in farm 2 significantly higher $40.8 \mathrm{~kg}$ grain $\mathrm{kg} \mathrm{N}$ applied $^{-1}$ and lower $415.4 \mathrm{~kg}$ grain $\mathrm{kg} \mathrm{N}$ applied $^{-1}$ of agronomic nitrogen efficiency was obtained from plot treated with $23 \mathrm{~kg} \mathrm{~N} \mathrm{ha}^{-1}$ (50 kg ha-1 urea stable) applied in split and $46 \mathrm{~kg} \mathrm{~N} \mathrm{ha}^{-1}$ or (100 kg ha-1 urea stable) applied only at planting. Agronomic nitrogen efficiency was higher at lower nitrogen rate and this indicates efficient use of nutrient by plants when applied in low dose. Similarly, the highest agronomic efficiency nitrogen was reported when lowest nitrogen rate $\left(46 \mathrm{~kg} \mathrm{~N} \mathrm{ha}^{-1}\right)$ applied in three splits $1 / 4$ at planting, $1 / 2$ at tillering and $1 / 4$ at anthesis [35]. The apparent nitrogen recovery efficiency of wheat during 2018 cropping season was showed significant $(\mathrm{P}<0.05)$ difference among applied urea stable and conventional urea fertilizer rates in farm one and farm two (Table 5).

Table 5. Effect of urea stable and urea on agronomic, physiological and apparent recovery efficiency wheat on Vertisols in 2018 cropping season.

\begin{tabular}{|c|c|c|c|c|c|c|}
\hline \multirow[t]{2}{*}{ Treatment ( $\left.\mathrm{kg} \mathrm{N} \mathrm{ha}{ }^{-1}\right)$} & \multicolumn{2}{|c|}{$\begin{array}{l}\text { Agronomic Nitrogen efficiency (kg } \\
\text { grain } \mathrm{kg} \mathrm{N}^{-1} \text { applied) }\end{array}$} & \multicolumn{2}{|c|}{$\begin{array}{l}\text { Apparent nitrogen recovery } \\
\text { efficiency }(\%)\end{array}$} & \multicolumn{2}{|c|}{$\begin{array}{l}\text { Physiological nitrogen efficiency } \\
\text { (kg grain } \mathrm{Kg} \mathrm{N}^{-1} \text { uptake) }\end{array}$} \\
\hline & Farm1 & Farm 2 & Farm1 & Farm 2 & Farm1 & Farm 2 \\
\hline 0 & - & - & - & - & - & - \\
\hline $46 \mathrm{~N}$ from US. at planting & 19.87 & 22 & $48.1^{\mathrm{c}}$ & $65.9^{\mathrm{a}}$ & $0.71^{\mathrm{ab}}$ & $0.46^{\mathrm{bc}}$ \\
\hline $46 \mathrm{~N}$ from US. in split & 18.53 & 25.5 & $40.0^{\text {cde }}$ & $38.8^{\mathrm{d}}$ & $0.49^{\text {cd }}$ & $0.72^{\mathrm{b}}$ \\
\hline $23 \mathrm{~N}$ from US. at planting & 30.6 & 21.5 & $77.4^{\mathrm{a}}$ & $58.5^{\mathrm{b}}$ & $0.48^{\mathrm{cd}}$ & $0.70^{\mathrm{b}}$ \\
\hline $69 \mathrm{~N}$ from US in split & 25.27 & 29.5 & $32.3^{\mathrm{de}}$ & $41.6^{\mathrm{d}}$ & $0.81^{\mathrm{ab}}$ & $0.72^{\mathrm{b}}$ \\
\hline $69 \mathrm{~N}$ from NU in split & 27 & 19.5 & $36.9^{\text {de }}$ & $42.8^{\mathrm{cd}}$ & $0.62^{\text {bcd }}$ & $0.57^{\mathrm{bc}}$ \\
\hline $69 \mathrm{~N}$ from US at planting & 22.2 & 15.4 & $41.7^{\mathrm{cd}}$ & $49.6^{\mathrm{c}}$ & $0.45^{\mathrm{d}}$ & $0.33^{\mathrm{c}}$ \\
\hline LSD (5\%) & 12.6 & 22.6 & 9.61 & 7.3 & 0.216 & 0.3463 \\
\hline $\mathrm{CV}(\%)$ & 13.75 & 17.34 & 11.77 & 8.92 & 19.34 & 28.41 \\
\hline
\end{tabular}

Means followed by different letter (s) in a column are not significantly different at $5 \%$ probability level.

\subsubsection{Apparent Nitrogen Recovery Efficiency}

The mean value of wheat apparent nitrogen recovery efficiency was ranged from 30.4-77.4\% in farm one with application of $69 \mathrm{~kg} \mathrm{~N} \mathrm{ha}^{-1}$ from urea stable applied in split and $23 \mathrm{~N}$ from urea stable applied at planting. In farm two, apparent nitrogen recovery efficiency value ranged from 37 to $65.9 \%$ was obtained with application of $23 \mathrm{~kg} \mathrm{~N}^{-1}$ from urea stable applied in split and $46 \mathrm{~kg} \mathrm{~N} \mathrm{ha}^{-1}$ from urea stable applied at planting. Likewise, [35] was also reported the highest apparent nitrogen recovery efficiency of $75 \%$ and $81 \%$ in 2013 and 2014 cropping seasons when $69 \mathrm{~kg} \mathrm{~N}$ ha $^{-1}$ applied in split. Apparent nitrogen recovery efficiency of 70 to $131 \%$ was also reported by [37, 38]. Similarly, [39] was also reported apparent nitrogen recovery efficiency ranging $53 \%$ and $86 \%$ by application different nitrogen rates. The apparent nitrogen recovery efficiency values for wheat in a well-managed system or low soil $\mathrm{N}$ supply was ranged between $50-80 \mathrm{~kg} \mathrm{~kg}^{-1}$ [40].

\subsubsection{Physiological Nitrogen Efficiency}

The physiological nitrogen efficiency of wheat during 2018 cropping season was showed significant $(\mathrm{P}<0.05)$ difference with application of urea stable and conventional urea in both farmers field (Table 5). The value of wheat physiological efficiency was ranged from 0.45 to 0.86 and 0.33 to $1.37 \mathrm{~kg}$ grain $\mathrm{kg}^{-1} \mathrm{~N}$ uptake at farm one and two respectively. In both farmers field the highest and lowest values were obtained with application of $69 \mathrm{~kg} \mathrm{~N} \mathrm{ha}^{-1}$ from urea stable applied at planting and $23 \mathrm{~kg} \mathrm{~N}^{-1}$ from urea stable applied in spilt respectively. Similarly, [35] reported the physiological utilization efficiency of 55 and $78 \mathrm{~kg}$ of grain $\mathrm{kg}^{-1}$ of $\mathrm{N}$ uptake in 2013 and 20014 cropping seasons where $46 \mathrm{~kg} \mathrm{~N} \mathrm{ha}^{-1}$ applied in three splits $1 / 4$ at planting, $1 / 2$ at tillering and $1 / 4$ at anthesis. [41] pointed out that there was a significantly $\mathrm{N}$ utilization efficiency and $\mathrm{N}$ use efficiency for grain yield when $\mathrm{N}$ was applied $1 / 4$ at planting, $1 / 2$ at midtillering, and 1/4 at anthesis. [34] also reported significant effect nitrogen fertilizer on mean nitrogen use efficiency of wheat varieties and NUE. According to the authors NUE of wheat crop was decreased to almost half as the amount of $\mathrm{N}$ fertilizer increased from 50 to $100 \mathrm{~kg} \mathrm{ha}^{-1}$.

\section{Conclusion}

The total nitrogen content of the experimental site was found in low range and indicated the need for application of nitrogen fertilizer from different sources. The applications of urea stable and conventional urea were significantly improved growth yield and yield components of wheat as compared to control. Mean plant height, spike length harvest index and thousand seed weight of wheat was significantly affected by nitrogen rate and increased with increasing of nitrogen rate applied from urea stable and conventional urea. 
Higher mean grain yield of $3623 \mathrm{~kg} \mathrm{ha}^{-1}$ and $3622 \mathrm{~kg} \mathrm{ha}^{-1}$ were harvested by application of $69 \mathrm{~kg} \mathrm{~N} \mathrm{ha}^{-1}$ in the form of urea stable and conventional urea respectively. The combined mean dry biomass of wheat was significantly improved with application of nitrogen rate and increased with increasing rate of nitrogen fertilizer. The highest $\left(8921 \mathrm{~kg} \mathrm{ha}^{-1}\right)$ and lowest $\left(4564 \mathrm{~kg} \mathrm{ha}^{-1}\right)$ mean dry biomass were recorded from split application of $69 \mathrm{~kg} \mathrm{~N} \mathrm{ha}^{-1}$ in the form of urea stable and control treatment respectively. Thus, the application of equal rate of urea stable in split or at planting was provided statistically the same yield and yield components of wheat crop with split application of conventional urea. In general, significant effect of application time of urea stable at each similar rate was not observed and this can be due to slow releasing of nitrogen from urea stable fertilizer. Therefore, urea stable can be used as alternative in addition to conventional urea if the cost of this fertilizer is the same with convectional urea.

\section{Acknowledgements}

We would like to thank the almighty God who helped us to see seed of our research work. The authors thank Natural Resources Management Research Process for funding the experiment. We are very grateful to Ambo Agricultural Research center management for providing all necessary equipment's and logistics during the research work. All the technical and field assistants of Natural Resources Management Research Process are also acknowledged for unreserved effort during executing the experiment. We want to thank farmers for providing us land for field research work and their assistance in field management activities for the experiment.

\section{References}

[1] Malhi, S. S., Grant, C. A., Johnston, A. M. and Gill, K. S. 2001. Nitrogen fertilization management for no-till cereal production in the Canadian Great Plains: a review. Soil and Tillage Research, 60: 101-122.

[2] Spiertz. J. H. J. 2010. Nitrogen, sustainable agriculture and food security. A review. Agronomy for Sustainable Development, 30 (1): 43-55.

[3] FAO (Food and Agriculture Organization). 2008. Guidelines on Nitrogen Management in Agricultural Systems: Training course series No. 29, Austria.

[4] Dai, X., Ouyang, Z., Li, Y. and Wang H. 2013. Variation in Yield Gap Induced by Nitrogen, Phosphorus and Potassium Fertilizer in North China Plain. PLos one, 8 (12): 1-8.

[5] Williamson. J. M. 2011. The Role of Information and Prices in the Nitrogen Fertilizer management Decision: New Evidence from the Agricultural Resource Management Survey. Journal of Agricultural and Resource Economics, 36 (3): 552572.

[6] Xiangbei D., Min X. and Lingcong K. 2019. Split application of reduced nitrogen rate improves nitrogen uptake and use efficiency in sweet potato. Springer, 9: $14058 \mathrm{https}$ : doi.org/10.1038/s41598-019-50532-2.

[7] Bouwman A. F., Boumans L. J. and Batjes N. H. 2002. Emissions of $\mathrm{N} 2 \mathrm{O}$ and $\mathrm{NO}$ from fertilized fields: summary of available measurement data. Global Biogeochemical Cycles, 16 (4): 6-13.

[8] Finck, A. 1992. Fertilizers and their efficient use. In: World Fertilizer Use Manual. Halliday, D. J., Renkel, M. E. and Wichmann, W. (Eds). International Fertilizer Industry Association, Paris, France.

[9] Fresew, B., Nigussie, D., Adamu, M. and Tamado, T. $2018 \mathrm{~b}$. Effect of split application of different $N$ rates on productivity and nitrogen use efficiency of bread wheat (Triticum aestivum L.). Agriculture and Food Security, 7 (92), doi: 10.1186/s40066-018-0242-9.

[10] Fresew, B., Nigussie, D., Adamu, M. and Tamado, T. 2018a. Effect of nitrogen fertilizer rates on grain yield and nitrogen uptake and use efficiency of bread wheat (Triticum aestivum L.) varieties on the Vertisols of central highlands of Ethiopia. Agriculture and Food Security, 7 (78): 1-12.

[11] Cantarella. H., Otto, R., Soares, J. R. and Silva, A. G. 2018. Agronomic efficiency of NBPT as a urease inhibitor: A review. Journal of Advanced Research, 13: 19-27.

[12] Minot, N., Warner, J., Lemma, S., Kasa, L., Gashaw, A. and Rashid, S. 2015. The Wheat Supply Chain in Ethiopia: Patterns, trends, and policy options. International Food Policy Research Institute (IFPRI), Addis Ababa, Ethiopia.

[13] CSA (Central Statistical Agency). 2018. Agricultural Sample Survey 2017/18 (2010 E. C) volume I: Technical Report on Area and Production for Major Crops. Statistical Bulletin No. 584. Addis Ababa, Ethiopia.

[14] Zenabu, B., Heluf, G. and Wassie, H. 2018. Characterization of Soil Fertility for Wheat Production at Shiebench District in Bench Maji Zone, Southern Ethiopia. Agriculture Resource and Technology: Open Access Journal, 15 (4): 1-9.

[15] Kidane, G. 2015. Dryland Agriculture Production Systems in Ethiopia. National Publishers, Addis Ababa, Ethiopia.

[16] Fageria, N. K. 2014. Nitrogen harvest index and its association with crop yields. Journal of Plant Nutrition, 37: 795-810.

[17] Tadesse, D. and Bobe, B. 2016. Effect of Drain Depth of Vertisols, Nitrogen Source and Time of Application on Yield and Yield Components of Maize (Zea Mays L.) in Ambo, Western Ethiopia. International Journals of Research Studies in Agricultural Sciences, 2 (6): 1-9.

[18] Dewis, J. and Freitas, F. 1984. Physical and chemical methods of soil and water analysis. FAO Soil Bulletin No. 10. FAO, Rome. 275 pp.

[19] Walkley, A. and Black, C. A. 1934. An examination of Degtjareff method for determining soil organic matter and the proposed modification of the chromic acid titration method. Soil Sciences. 37: 29-38.

[20] Bremner, J. M. and Mulvaney, C. S. 1982. Nitrogen-total. In: Methods of Soil Analysis. pp. 595-624. In: Page, A. L., Miller, R. H. and Keeney, D. R. (Eds.), Part 2. Chemical and microbiological properties. 2nd edition, American Society of Agronomy. Madison, WI 53711, USA. 
[21] Polemio, M. and Rhoades, J. D. 1977. Determining cation exchange capacity: A new procedure for calcareous and gypsiferous soils. Soil Science Society America Journal. 41: 524-528.

[22] Rhoades, J. D. 1982. Cation Exchange Capacity. In: Methods of Soil analysis. pp. 149-157. In: Page A. L, Miller, R. H. and Keeney, D. R. (Eds), Part 2. Chemical and Microbiological Properties. Agronomy Monograph no. 9. $2^{\text {nd }}$ Edition. Agronomy society America-Soil Science Society America, 677 S. Segoe Rd., Madison, WI 53711, USA.

[23] Bray, H. R. and Kurtz, L. T. 1945. Determination of organic and available forms of phosphorus in soils. Soil Science. 9: $39-46$.

[24] Jones, J. B. and Case, V. W. 1990. Sampling, Handling, and Analysing Plant Tissue Samples. pp. 389-427. In: Westermann, R. L. (Ed). Soil Testing and Plant Analysis Book Series no. 3. Soil Science Society of America, Madison WI.

[25] Cleemput, O. V., Zapata, F. and Vanlauwe, B. 2008. Use of tracer technology in mineral fertilizer management. In: Guidelines on Nitrogen Management in Agricultural Systems. International Atomic Energy Agency, Austria, Vienna, pp. 19126.

[26] Azizian, A. and Sepaskhah, A. R. 2014. Maize response to different water, salinity and nitrogen levels: Agronomic behavior. International Journal of Plant Production. 8: 107130.

[27] SAS. 2012. SAS/STAT Software Syntax, Version 9.4. SAS Institute, Cary, NC. USA.

[28] Steel, R. G. D., Torrie, J. H. and Dicky, D. A. 1997. Principles and Procedures of Statistics, A Biometrical Approach. $3^{\text {rd }}$ Edition, McGraw Hill, Inc. Book Co., New York, pp: 352-358.

[29] Tekalign, T. 1991. Soil, plant, water, fertilizer, animal manure and compost analysis: Working Document No. 13. International Livestock Research Center for Africa, Addis Ababa.

[30] Jones, J. B. 2003. Agronomic Handbook: Management of Crops, Soils, and their Fertility. CRC Press LLC, Boca Raton, FL, USA. 482pp.

[31] Marcelo, C., Espindula,, V. S. R., Moacil, A. de S., Marcela. C. and Guilherme, de S. P. 2013. Rates of urea with or without urease inhibitor for topdressing wheat. Chilean Journal of Agricultural Research, 73 (2): 160-167.
[32] Yohannes, E. and Nigussie, D. 2019. Effect of Rates and Time of Nitrogen Application on Growth, Yield, and Yield Components of Wheat (Triticum aestivum L.) in Eastern Hararghe, Ethiopia. Journal of Natural Sciences Research. 9 (11): 1-15.

[33] Sofonyas, D., Lemma, W. and Selamyihun, K. 2018. Response of Bread Wheat (Triticum aestivum L.) to Application of Slow Releasing Nitrogen Fertilizer in Tigray Ethiop. Journal of Agricultural Science, 28 (1): 111-126.

[34] Serret, M. D., Ortiz-Monasterio, I., Pardo, A. and Araus, J. L. 2008. The effects of urea fertilization and genotype on yield, nitrogen use efficiency, ${ }^{15} \mathrm{~N}$ and ${ }^{13} \mathrm{C}$ in wheat. Annals of Applied Biology. 153: 243-257.

[35] Beyenesh, Z., Nigussie, D. and Fetien, A. 2017. Yield and Nutrient Use Efficiency of Bread Wheat (Triticum Aestivum L.) as Influenced by Time and Rate of Nitrogen Application in Enderta, Tigray, Northern Ethiopia. Open Agriculture. 2: 611624.

[36] Alamzeb, M., Anwar, S., Iqbal, A., Parmar, B. and Iqbal, M. 2017. Organic sources, nitrogen and tillage systems improve wheat productivity and profitability under semiarid climates. Journal of Pharmacognosy and Phytochemistry. SP1: 73-78.

[37] Amanuel, G. and Tanner, D. G. 1991. The effect of crop rotation in two wheat production zones of southeastern Ethiopia. pp. 491-496. In: Saunders, D. (Ed.), Wheat for the Non-traditional Warm Areas (July 29-August 3 1990, Foz do Iguaçu, Brazil), CIMMYT, Mexico, DF.

[38] Amsal, T. and Tanner, D. G. 2001. Effects of fertilizer application on $\mathrm{N}$ and $\mathrm{P}$ uptake, recovery and use efficiency of bread wheat grown on two soil types in central Ethiopia, Ethiopian Journal of Natural Resources, 3 (2): 219-244.

[39] Genene, G. 2003. Yield and quality response of bread wheat varieties to rate and time of nitrogen fertilizer application at Kulumsa, southern Ethiopia, M. Sc Thesis, Alemaya University, Alemaya, Ethiopia. 120 pp.

[40] Dobermann A. R. 2005. Nitrogen Use Efficiency State of the Art. Agronomy and Horticulture Faculty Publication, University of Nebraska, Lincoln. Paper. 316.

[41] Dressa, H., Nigussie, D. and Amsalu, A. 2012. Nitrogen use efficiency of bread wheat: Effects of nitrogen rate and time of application. Journal Soil Science and Plant Nutrition. 12 (3): 389-409. 